\title{
Letter to Editor
}

(C) 2021 Serpa et.al.. This is an open access article licensed under the Creative Commons Attribution-NonCommercial 4.o International License (https://creativecommons.org/licenses/by-nc/4.o/)

Received: 30 November 2020 / Accepted: 8 January 2021 / Published: 5 March 2021

\section{COVID-19 and Scientific Literacy}

\author{
Sandro Serpa \\ University of the Azores, Faculty of Social and Human Sciences, Department of Sociology; \\ Interdisciplinary Centre of Social Sciences - CICS.UAc/CICS.NOVA.UAc; \\ Interdisciplinary Centre for Childhood and Adolescence - NICA - UAc, Portugal

\section{Carlos Miguel Ferreira} \\ Interdisciplinary Centre of Social Sciences - CICS.NOVA; \\ Estoril Higher Institute for Tourism and Hotel Studies, Portugal

\section{Maria José Sá} \\ CIPES - Centre for Research for Higher Education Policies, Portugal

\section{Ana Isabel Santos} \\ University of the Azores, Faculty of Social and Human Sciences, Department of Sociology; \\ Interdisciplinary Centre for Childhood and Adolescence - NICA - UAc, Portugal
}

DOI: https://doi.org/10.36941/jesr-2021-0024

\section{Abstract}

The COVID-19 pandemic is, currently, the focus of all personal and collective actions at the social, cultural, economic, political and religious levels, among other dimensions of human life. This Letter to the Editor focuses on the overwhelming existence of fake news directly related to COVID-19, which permeate social networks and even the media, where journalists should act as gatekeepers and not fake-keepers. The methodology used in the collection and selection of data consisted of bibliographic research, in international databases, of publications on the topic under study and their content analysis. The results allow concluding that there is a need to promote scientific literacy in the general population but especially among journalists themselves.

Keywords: COVID-19, SARS-COV-2, infodemic, scientific literacy, fake news, pseudoscience, social media, public health

The pandemic caused by the COVID-19 disease is the consequence of an infectious triggered by a severe acute respiratory syndrome (SARS-CoV-2), and it can already be considered as having highly negative consequences in several dimensions, such as social, individual and collective health, economic and psychiatric, among others). This pandemic shapes, currently, all personal and collective actions, whether at a social, cultural, economic, political or religious level (Biasio, Bonaccorsi, Lorini, \& Pecorelli, 2020; Ferreira, Sá, Martins, \& Serpa, 2020; Sá \& Serpa, 2020a, 200ob, 2000c; Setiawan, 2020; Li \& Liu, 2020; Halat et al., 2020). For Biasio et al. (2020), 
[...] the level of uncertainty was still extremely high and exacerbated by an excess of contradictory information. Many laic media and web sites have delivered unceasingly real time numbers on new cases and deaths, also providing medical advices, although not entitled, often getting ahead of evidence. The amount and variety of news has led to a massive informative overload, generating a real infodemic (p.1).

According to Anwar, Malik, Raees, and Anwar (2020), the COVID-19 infodemic is a mixture of two words, "information' and 'epidemic', and refers to a rapid and far-reaching spread of both accurate and inaccurate information about a disease. During a pandemic, when facts are often mixed with rumours, it becomes challenging to learn essential information about an issue" (p. 10). In pandemic situations, for example, there is an excessive and potentially contradictory or confusing amount of information, or that tends to generate misinformation (Naeem \& Bhatti, 2020). In the specific case of COVID-19, this results in the overload of information and misinformation about the pandemic in traditional media, but especially in social media/digital social networks, namely its origin, transmission, diagnosis and treatment in a pandemic context, among other negative limitations. This naturally hampers the combat against this pandemic, both preventatively and curatively, generating higher uncertainty (Naeem \& Bhatti, 2020; Biasio et al., 2020; Anwar et al., 2020; Amit Aharon, Ruban, \& Dubovi, 2020; Li \& Liu, 2020; Halat et al., 2020; Al-Zaman, 2020; Abdulai, Tiffere, Adam, \& Kabanunye, 2021; Stokken \& Børsen, 2020). In this regard, Peters and Besley (2020) argue that,

With the increasing use of social media by many people, and where many actually get their news from social media rather than traditional media sources (newspapers, TV, and journals) amidst the Covid-19 pandemic, there is a huge increase in the number and influence of conspiracy theories world-wide. This has meant that those who believe and follow such theories are more likely to reject official health advice and government instructions, amid science denialism, anti-scientism and a distrust of experts, as well as politicians ( $p .5)$.

This situation is aggravated by the fact that many media consumers and users of digital networks are very uncritical and tend to believe in information that confirms their existing beliefs (Rothmund, Farkhari, Azevedo, \& Ziemer, 2020; Rosenthal, 2020; Amit Aharon et al., 2020; Santos \& Serpa, 2017; Peters \& Besley, 2020; Rosenthal, 2020; Abdulai et al., 2021; Ferreira \& Serpa, 2020). However, Anwar et al. (2020) maintain that "The role of media and public health communications must be understood and explored further as they will be an essential tool for combating COVID-19 and future outbreaks" (p. 1).

Naeem and Bhatti (2020) make, in their recent work, a summary of the most common myths that gained strength during the COVID-19 pandemic and that are listed below.

- Drinking alcohol protects you against COVID-19

- Spraying alcohol or chlorine all over your body kills the new coronavirus

- Eating garlic helps prevents infection with the new coronavirus

- The COVID-19 virus cannot be transmitted in areas with hot and humid climates

- Cold weather and snow kill the new coronavirus

- Taking a hot bath prevents the new coronavirus disease

- The new coronavirus can be transmitted through mosquito bites

- Hand dryers are effective in killing the new coronavirus

- Ultraviolet disinfection lamps kill the new coronavirus

- Mosquito bites can transmit the virus

- Chloroquine is a proven cure

- 5 G caused the pandemic (p. 234).

This misinformation on COVID-19 may even call into question the scientific studies produced on it (McGinnis, 2020; Al-Zaman, 2020; Rothmund et al., 2020) and permeates social networks and even the media, where journalists should act as gatekeepers, rather than fake-keepers:

In the age of digital communication and social networking, it gets a new momentum worldwide. We call 
it in many names: misinformation, disinformation, false news, inaccurate news, and rumor, though the problem remains almost the same. Amid the COVID-19 pandemic, the world is in grief with half a million dead. Health-related uncertainties give birth to a new phenomenon that is addressed as infodemic (a portmanteau of "information" and "epidemic"). In this situation, both true and false information galore. While true information helps to mitigate the crisis, false information amplifies it (Al-Zaman, 2020, p. 1).

All of this results in the need to promote better scientific literacy in the critical and well-founded distinction, if possible, between facts and valuation opinions (Aristeidou \& Herodotou, 2020; Stokken \& Børsen, 2020; McGinnis, 2020; Laugksch, 2000), to shape a better response and management of the COVID-19 pandemic (Li \& Liu, 2020; Naeem \& Bhatti, 2020; Anwar et al., 2020; Ferreira \& Serpa, 2020). In this process of fostering scientific literacy, interdisciplinarity plays an extremely important role (Anderson, Justement, \& Bruns, 2020; Serpa, Ferreira, \& Santos, 2017; Reiss, 2020).

Anwar et al. (2020) summarise well the pivotal role of the media in managing the pandemic caused by COVID-19. Given the centrality of the role of the media, the authors recommend the development of a model to assess the response of the media to epidemic or pandemic situations. "This evaluation can serve as feedback for the media to help devise better and more effective strategies to control and prevent subsequent outbreaks" (p. 10).

\section{Acknowledgment}

Funding: University of Azores, Interdisciplinary Centre of Social SciencesCICS.UAc/CICS.NOVA.UAc, UID/SOC/04647/2020, with the financial support of FCT/MEC through national funds and when applicable co-financed by FEDER under the PT2020 Partnership Agreement.

\section{References}

Abdulai, A.-F., Tiffere, A.-H., Adam, F., \& Kabanunye, M. M. (2021). COVID-19 information-related digital literacy among online health consumers in a low-income country. International Journal of Medical Informatics, 145, 104322. https://doi.org/10.1016/j.ijmedinf.2020.104322

Al-Zaman, M. S. (2020). COVID-19-related fake news in social media. MedRxiv, Preprints. https://doi.org/10.1101/2020.07.06.20147066

Amit Aharon, A., Ruban, A., \& Dubovi, I. (2020). Knowledge and information credibility evaluation strategies regarding COVID-19: A cross-sectional study. Nursing Outlook. https://doi.org/10.1016/j.outlook.2020.09.001

Anderson, A. E., Justement, L. B., \& Bruns, H. A. (2020). Using real-world examples of the COVID-19 pandemic to increase student confidence in their scientific literacy skills. Biochemistry and Molecular Biology Education, 48, 678-684. https://doi.org/10.1002/bmb.21474

Anwar, A., Malik, M., Raees, V., \& Anwar, A. (2020). Role of mass media and public health communications in the COVID-19 pandemic. Cureus, 12(9), e10453. https://doi.org/10.7759/cureus.10453

Aristeidou, M., \& Herodotou, C. (2020). Online citizen science: A systematic review of effects on learning and scientific literacy. Citizen Science: Theory and Practice, 5(1). http://doi.org/10.5334/cstp.224

Biasio, L. R., Bonaccorsi, G., Lorini, C., \& Pecorelli, S. (2020). Assessing COVID-19 vaccine literacy: A preliminary online survey. Human Vaccines E Immunotherapeutics, Ahead-of-print, 1-9. https://doi.org/10.108o/21645515.2020.1829315

Ferreira, C. M., Sá, M. J., Martins, J. G., \& Serpa, S. (2020). The COVID-19 contagion-pandemic dyad: A view from social sciences. Societies, 10(4), 77, 1-19. https://doi.org/10.339o/soc10040077

Ferreira, C. M., \& Serpa, S. (2020). Contagions: Domains, challenges and health devices. Academic Journal of Interdisciplinary Studies, 9(4), 1-14. https://doi.org/10.36941/ajis-2020-0056

Laugksch, R. C. (2000). Scientific literacy: A conceptual overview. Science Education, 84, 71-94. https://doi.org/10.1002/(SICI)1098-237X(200001)84:1<71::AID-SCE6>3.0.CO;2-C

Li, X. \& Liu, Q. (2020). Social media use, eHealth literacy, disease knowledge, and preventive behaviors in the COVID-19 pandemic: Cross-sectional study on Chinese netizens. Journal of Medical Internet Research, 22(10), e19684. http://doi.org/10.2196/19684 
Halat, D. H., Akel, M., Hajj, F., HajjHussein, H., Kansoun, R., Sharif-Askari, E., ... Faraj, A. (2020). Insights into the positive role of a higher education institution in the prevention of misinformation during pandemics: The Health Committee Model during COVID-19. Coronaviruses (E-pub Ahead of Print), o1. https://doi.org/https://doi.org/10.2174/2666796701999200915145332

McGinnis, P. (2020). From the editor's desk: Scientific literacy in the post-truth era. Science Scope, 43(5). https://doi.org/10.2505/4/ss20_043_05_1

Naeem, S. B., \& Bhatti, R. (2020). The Covid-19 "infodemic": A new front for information professionals. Health Information E Libraries Journal, 37(3), 233-239. https://doi.org/10.1111/hir.12311

Peters, M., \& Besley, T. (2020). Education and the new dark ages? Conspiracy, social media and science denial. ACCESS: Contemporary Issues in Education, 40(1), 5-14. https://doi.org/10.46786/ac20.3082

Reiss, M. J. (2020). Science education in the light of COVID-19. Science $\mathcal{E}$ Education, 29(4), 1079-1092. https://doi.org/10.1007/s11191-020-00143-5

Rosenthal, S. (2020). Media literacy, scientific literacy, and science videos on the internet. Frontiers in Communication, 5. https://doi.org/10.3389/fcomm.2020.581585

Rothmund, T., Farkhari, F., Azevedo, F., \& Ziemer, C.-T. (2020). Scientific trust, risk assessment, and conspiracy beliefs about COVID-19 - Four patterns of consensus and disagreement between scientific experts and the German public. PsyArXiv Preprints. https://doi.org/10.31234/osf.io/4nzuy

Sá, M. J., \& Serpa, S. (2020a). The COVID-19 pandemic as an opportunity to foster the sustainable development of teaching in higher education. Sustainability, 12(20), 8525, 1-16. https://doi.org/10.339o/su12208525

Sá, M. J., \& Serpa, S. (2020b). COVID-19 and the promotion of digital competences in education. Universal Journal of Educational Research, 8(10), 4520-4528. https://doi.org/10.13189/ujer.2020.081020

Sá, M. J., \& Serpa, S. (2020c). The global crisis brought about by SARS-CoV-2 and its impacts on education: An overview of the Portuguese panorama. Science Insights Education Frontiers, 5(2), 525-530. https://doi.org/doi:10.15354/sief.2o.aro39

Santos, A. I., \& Serpa, S. (2017). The importance of promoting digital literacy in higher education. International Journal of Social Science Studies, 5(6), 90-93. https://doi.org/10.11114/ijsss.v5i6.2330

Serpa, S., Ferreira, C. M., Santos, A. I. (2017). Fostering interdisciplinarity: Implications for social sciences. International Journal of Social Science Studies, 5(12). 44-49. https://doi.org/10.11114/ijsss.v5i12.2775

Setiawan, A. R. (2020). Scientific literacy worksheets for distance learning in the topic of coronavirus 2019 (COVID19). EdArXiv Preprints. https://doi.org/10.35542/osf.io/swjmk

Stokken, R., \& Børsen, T. (2020). Scientific literacy in a digital world. In L. J. Halvorsen, R. Stokken, W. M. Rogne, \& I. J. Erdal (Eds.), Digital samhandling. Fjordantologien 2020 [Digital interaction. Fjordantologien 2020] (pp. 25-39). https://doi.org/10.18261/9788215037394-2020-02 